\title{
Philosophy of Intonation in Sergey Taneyev's Cantatas
}

\author{
Galima Lukina \\ Russian State Specialized Arts Academy \\ Moscow, Russia \\ e-mail: galimalukina@yandex.ru
}

\begin{abstract}
This article aims to give a religious and philosophical interpretation of Sergey Taneyev's cantatas "St. John Damascene" and "On reading Psalm". By means of united philosophical and musicological methodologies, a study of both cantatas is made that shows the connection between the composer's ideas from the Russian religious-philosophical tradition and his creative priority of reviving the tradition of choral music.
\end{abstract}

Keywords-Sergey Taneyev; cantatas; Russian tradition revealing; St. John Damascene; On reading Psalm; choral music

\section{INTRODUCTION}

The main problem raised in this article is the interpretation of Sergey Taneyev's cantatas "St. John Damascene" and "On reading Psalm" in their religious and philosophical aspects.

Each language of art expresses the word-view of the artist, his national culture, and the period in which he lived. Musical art, because of the intonation in its nature, shows in the most evident way the essential aspect of culture as an ideal-forming sphere of human life. As such, music can serve as an especially productive material for philosophical and culturological research.

A composer's art is a kind of philosophizing. Proper musicology alone is unable to reveal the meaning of a musical composition; only when combined with philosophical and ontological methods can musicology offer a complete understanding of a musical text without destroying the unity of form and content.

The study of Taneyev's cantatas using such a combined method shows the connection of the great Russian composer with the theo-philosophical tradition. This tradition is evident in the range of his ideas as well as in his creative priority in reviving the tradition of choral music. It is logical that Taneyev aimed to develop the national music tradition by creating an "orthodox cantata". This technique is similar to that of Bach's national tradition in German music. Taneyev attributed to the genre of cantata the ability to "express in general (way) the essential features of modern understanding of Man in order to unite people in an ideal community" [1]. Taneyev realized only religious music, being what he considered a source of the highest national values, could fulfill this task.
Taneyev's reflection on the future of Russian music developed in his article "What do Russian composers have to do?" led to an idea of a certain genre expressing optimally either his own artistic priorities or his understanding of superior aims and the tasks of art. We should mention that Taneyev's interpretation of this genre is similar neither to its Russian form with its hymnal, salutatory character nor to Bach's version of spiritual cantata, although the Russian composer did use it as a kind of pattern.

\section{ABOUT THE IDEOLOGICAL UNITY OF THE POETIC WORD IN THE CANTATAS TANEYEV}

Notwithstanding the 31 years that came between "St. John Damascene" (1884) and "On reading Psalm" (1915) the semantic unity of both texts chosen by Taneyev in his young and mature age is amazing. The poetry of Alexey Tolstoy and of Alexey Homyakov is a quintessence of ideas concerning Taneyev throughout his creative work.

Taneyev has chosen a strophe from Tolstoy's poem "St. John Damascene" and a Homyakov's poem "On reading Psalm" in an attempt to poetically interpret Eastern Christian hymnography. Tolstoy's poem is a non-canonical versification of a funeral canticle said for the deceased with words full of love and prayers appealing to God. In the funeral ceremony "The Beatitudes" one of these canticles is said after each commandment. Homyakov's poem is a poetic version of a psalm.

Canticle and psalm belong among the genres with a didactic, preaching character. In ancient times, the word "canticle" was a synonym of "bible", which specifically meant an instructive book. Similarly, the Psalter was from the earliest times respected in Russia as a necessary book for daily reading that contributed to a Christian's spiritual development.

Homyakov's poem does not contain any direct analogy with any single text of Psalter, yet its content embraces the main subjects and ideas of the book.

The resemblance of both texts chosen by Taneyev also extends to their structure, the characteristic feature of which is an implicit dialogic character within a monologic form of expression. In both cases, there prevails an address in the first person: I (go, lie, don't hear, sleep) - my love doesn't 
die - brothers, I implore you - God! (Take your deceased servant!)

God's voice; He (judges) - My people (listen) - You (make) for me - I (have created) - I (have outlined, want, create, enlarge) - I (have poured) - He (is boiling, breaking) - The Earth (is burning incense) - It isn't Me? (who has lighted) - It isn't Me (who is throwing) - You (come!) - I (will accept) - I need heart, will, I need a brother, I need truth.

All personal pronouns are the versions of our "ego" (self), or its mirrored images. According to Sergey Bulgakov, a pronoun is an "ontological frame which can contain all the being and that of that very "self", in particular, as far as it is a part of the universe, as far as it is named." Apparently, while choosing the strophe, Taneyev attached great importance to the absence of personification. Having marked out the structure of the dialog-address of Tolstoy's poetic text, we reveal the gradual development of the designation of "myself", whose name is the soul of deceased person. Phrases such as "love doesn't die", "brothers, I implore you", "God, take" are signs of a concrete collective being. Death is shown here as a beneficial moment in the life of human soul, as death allows the eternal soul to shed its mortal body and enter the kingdom of heaven.

To describe the "myself" of Homyakov, let us use again Bulgakov's definition according to which the "self embraces everything and nothing: everything, for it can be brought into a predicative connection with everything, and nothing, for it is by itself not something in the world of ideas, it is not a word-idea, but it is a word-sign". The word "I" in Homyakov's poem has several names - "God's voice", "He", "The Earth", "Not Me". This reveals the idea of the apophatic or negative interaction with the knowledge of God. In the theological tradition of the Eastern Church this way is considered the perfect one because it establishes God's nature as Incognizable, for "all sorts of cognition have for their object what exists, but God is beyond the limits of the existing. To come nearer to Him one must reject everything what is below him, i.e. everything what exists" [2]. The ultimate aim of apophaticism is mystical association with God, or "obozhenie" which finds its realization in synergy. The divine grace, which is the presence of God in us, is revealed in cooperation with God.

Practically speaking, all creative work by Homyakov is an expression of an apophatic idea that God's "living truth" is beyond rational understanding and is a particular case of human cognition. It is impossible to gain the "whole mind" without Faith, which is, for Homyakov, a single whole with Love. Tolstoy's lyre also responds to the eternal voice of Faith and Love sounding "in one's heart of hearts". It is interesting that in "St. John" it is a human soul that is appealing to God, and in "Psalm" - the last opus of a mature person-- it is the voice of God that is appealing to the world. It seems that Taneyev also began to hear the sounds of the invisible world. It is also notable that both poetic versions of contact between the two worlds, the celestial and the terrestrial one, approve the eternal character of spiritual, "fraternal" love as a love for one's neighbor. It is a "priceless gift" impossible without peace, without a "heart clearer than gold', and without strong will and truth. This Love or "good will" is named by Sergey Trubetskoy a conciliar (sobornal) consciousness. It is an awareness of unity of all the world created, of the fact that a human personality only seems to be isolated and closed from the outside, but at the bottom of the heart, each subjective ego communicates and connects with all the other egos and with the universal objective being.

Alexey Tolstoy understands Love in much the same way:

Joined in one love, we are links of an endless chain

And we are fated to ascend together in the radiance of the eternal truth. (1858).

"Oh don't rush where the life is clearer and brighter"...

Homyakov also affirmed that “... spiritual harmony emerges only on the condition that humans will agree, by its pure and holy inducements (which are always those of love), with the character of God's will (that of love and holiness)" [3].

Life is understood by poetic thinkers as an ascent to the height of being - to the Spirit through the growth of Good or, in theological words, as an "obozhenie" (deification) of the world and of the humanity. It is through perfect love that the true being, the world of "blissful settlements", is revealed and realized.

\section{FEATURES OF INTONATIONAL DEPLOYMENT IN TANEYEV'S CANTATAS}

The unity of the ideas of proto-intonational sources, Homyakov's and Tolstoy's Word, predetermined the intonational resemblance of Taneyev's cantatas. It can be said "the true pure energy of prointonation directed towards the sense of the world" [4] gave rise to the intonations consonant with poetic word. The key to the musical-dramatic concept of both "St. John" and "Psalm" is the interaction and coordination of two intonational spheres corresponding to the two worlds of the celestial and the terrestrial one. The main point of this interaction in its figurative aspect is revealed in the light of the principal idea which can be defined in the following way: suffering accompanies a human being's desire for inner harmony, i.e. - that of the Spirit, which can be gained through the cooperation of human will and that of God, which is Love.

In "St. John" the intonation sphere of the celestial world includes such melodies as "So svyatymi upokoi" ("For the peace of the soul", orchestral introduction and choral conclusion, "Upokoi Gospodi dushu raba tvoego" ("God rest the soul of thy servant"), "Vechnaya pamyat" ("Eternal memory") and the theme of the central part "Fig.1" . Their characteristic features are close to liturgical, sacred music, even deliberately quoting the pannychida melodies. Similarly, the Latin (Gregorian) and echo chants perform the function of musical-verbal prayer. 



Fig. 1. Cantata "St. John Damascene". Part I

In Christian liturgy, they symbolize through the cantata the act of a soul's prayerful communication with God. This analogy can be confirmed with such characteristic features of religious singing present, including a diatonic character, a syllabic and choral constitution, and a steadiness of melodic movement relying on a "dome-shaped" figure.

The choice of intonation material can be explained not only with the "memorial" concept of the work written in commemoration of Nikolay Rubinstein, Taneyev's teacher and friend, but also with the substantial aspect of the melodies that importantly express the idea of death in its Christian interpretation, namely as a delivery of the soul from all terrestrial ties into the kingdom of God.

The image of spiritual desire can be found in the intonation development of the themes of "terrestrial sphere" including the themes of fugue in the first part "I'm starting on an unknown journey", "My eye has died down, my chest has got cold" (number 3 ) and of fugue in the third part. Their distinctive feature is the polyphonic principle of their development based on special types of melodic movement with a strongly pronounced affect. The intonations prevailing in the first part are those of suffering, supplication, effort, in the third part - those of active, energetic movement.

Regarding the relation "word-melos", Taneyev again can be compared with Bach, whose principal aim was to "convey by means of music a characteristic expression, to reveal a feeling hidden in the words, an affect which can be expressed by music" [5]. Definite meaning of the intonations of the human world reveals in constant intonations-symbols figures of cross and ascent (Fig. 2).

If we collect all movement types characteristic of the first part's theme melody, in the broader scheme obtained a certain "program" can be read: it is suffering, ascent and achievement of a goal.

Figurative and intonation line derivative of the motive of the cross is furthered by the theme "My eye has died down" (number 9). Alternating with the melody "God rest the soul..." it forms a part evoking figurative and semantic analogies with funeral rites. It also, based on the alternation of the declamatory melody "God rest the soul..." with other melodies, achieves more flexibility and greater range. The second theme of the cantata, expressing spiritual suffering, plays the role of a "petition" to the deceased ("on the kissing of the deceased") [6]. The motive of rising fifth with rhythmic stress on the upper sound and with its following filling accentuates the semantics of suffering "Fig.3" .

The idea of ascension finds its most vivid expression in the final Fugue "Fig.4" .

In contrast to the first part where the melodic aspiration was permanently accompanied by the figure of the cross, which symbolizes suffering and overcoming it, the finale is characterized by the accentuation of active movement and enthusiasm.

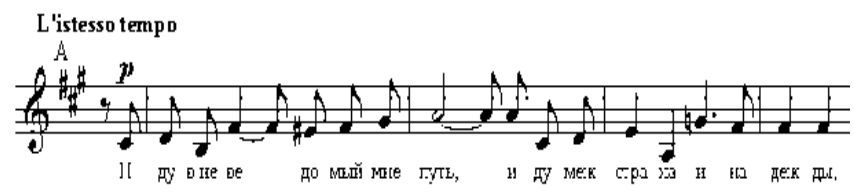

Fig. 2. Cantata "St. John Damascene". Fugue in Part I

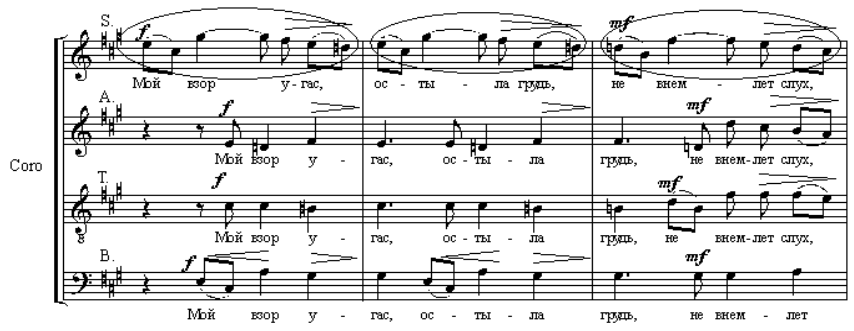

Fig. 3. Cantata "St. John Damascene". Part I 


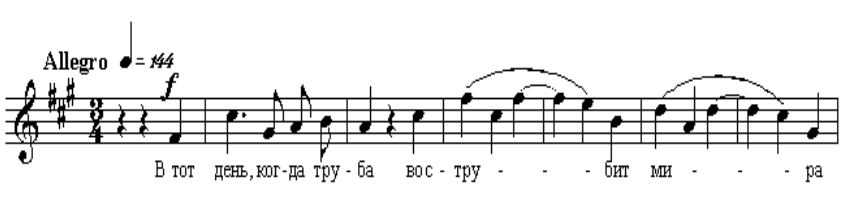

Fig. 4. Cantata "St. John Damascene". Part III

The finale's main theme, notwithstanding its origin (the motive of cross), is associated with aspiration and activity, for the melodical pattern of the intonations making it is founded on the figures of ascent and balance.

A significant transformation, or transfiguration, takes place by the end of the cantata under the influence of "celestial" intonational sphere. Thus, melodies "For the peace of the soul' (orchestral introduction and choral conclusion), "God rest the soul...", "Eternal memory', "squeezed" throughout the first part in the polyphonic development of the main fugue theme, seem to reduce the emotional "charge" of suffering permeating the "terrestrial" themes. They can be interpreted as a kind of symbol of a "celestial voice on earth" treating all terrestrial griefs and sorrows.

This idea (sorrow and, at the same time, hope for eternal life and the acceptance of death) is expressed most vividly in the melody "For the peace of the soul" opening the cantata. Initial choral sounding of the pannychida melody in the orchestral introduction reminds of conciliar prayerful intercession before God.

In view of the interpretation of the melody, we should pay attention to its melodic pattern. The first four sounds form a cross, a symbol of suffering and simultaneously the resurrection of Christ, therefore also symbolizing divine power and immortality. This figure is placed inside the phrase the pattern of which resembles a circle formed with two "bow-shaped" motives (Fig.4).

So we see a cross in a circle. It is hard to say if Taneyev knew the early Christian interpretation of this image symbolizing the unity of human and divine powers. But it is precisely this image that seems to contain the opus' "program", or "script" - a way through suffering and death to divine harmony and unity. This "program" can be seen in the form of the whole cantata:

Introduction - the celestial world;

Part 1 - The terrestrial world; human road of passion (Via Dolorosa);

Part 2 - The aim of the way: man reunited with God (the ideal demonstrated);

\section{Part 3 - The aim achieved (the ideal realized).}

The meaning of "For the peace of the soul" is revealed finally when it appears at the end of the cantata, after the theme of Via Dolorosa from the first part, powerfully interpreted by trumpets and trombones in a powerfull call. Performed by choir, "For the peace..." sounds like a prayer, pacificatory and otherworldly, expressing the spiritual unity achieved.
The same "program" is codified in the initial theme of the lyrical sphere of the cantata "On reading Psalm" which is marked by the same characteristic types of movement "Fig. 5 ".

The theme consists of two elements:

a) The motive based on a cruciform pattern with descending movement tending to lock in a circle prevailing;

b) The motive of ascending (rise) or call, directed high in the air, unlocking and extending the sound space outlined by the cross.

The image of a suffering person overcoming inner discord is revealed in full measure by the theme of the twovoice fugue in the second part (No.4) of "Psalm" "Fig.6" .

The theme is based on "cruciform" and descending chromatic motives. Saturated with instable and tense intonations, particularly accentuated by the sounding of men's voices, this theme presents a culmination of suffering.

After the central part of the cantata, the intonations with instable and strained character practically disappear (similarly to "St. John") and a sort of "trans figuration" of the terrestrial world takes place.

The role of the figurative sphere of the celestial world in "Psalm" is also similar to that of "St. John". Its intonation "sign" acts here as a "God's Voice", a "celestial contact" that makes a man feel himself as a living part of a living whole naming itself the Church" [7]. This sphere is united by the intonations of question, address, and appeal. All of them, in one way or another, are derived from the initial "Voice" founded on two-fold on a stable fifth move and an unstable one ascending by the steps of the triad "Fig. 2 " .

All the intonations forming the "celestial" sphere rise from this point and are present in an explicit or implicit way throughout the musical texture of the cantata:

No.3 "Why need I the vaults of pompous temples"

No.4 "Why need I gold"

No.5"Why incense"

No.6 "Why lights"

The way the spiritual formation is marked in the development of intonation is by the convergence and, in "Psalm", by the gradual fusion of both figurative-thematic spheres (as the subjective sphere transforms passing from strain, doubts, and an "invisible battle" to harmony coming from spiritual synergism).

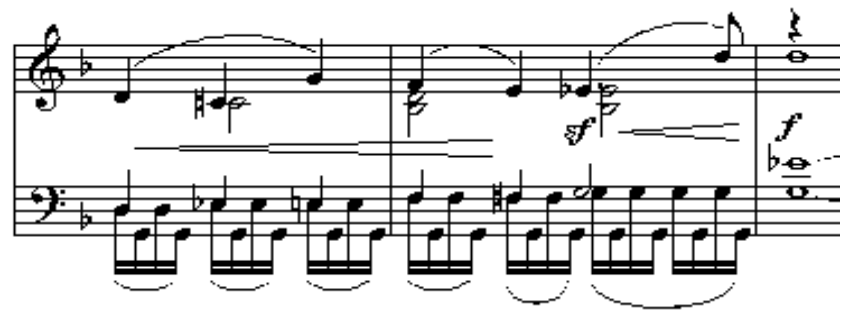

Fig. 5. Cantata “On reading Psalm”. Part I 


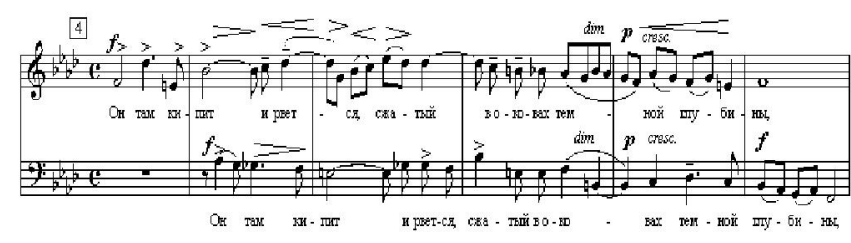

Fig. 6. Cantata "On reading Psalm". Fugue theme from Part II (No.4)

The principle of dialogic intonation development in Taneyev's cantatas

Figurative transformation is implemented at the composition level through the principle of dialogic intonation development and shown most evidently in the cantata "On reading Psalm". The dialogic character of poetical text is emphasized by appropriate musical means.

The dialogic character of musical development is already seen in the introduction where two key elements of melodic archetype of the cantata are interpreted as an antithesis: affirmation (the stability of fifth' motive) - question or call (instable ascending sixth' leap in dotted rhythm). The twofoldness of the initial theme marks a dialog between two figurative spheres, which becomes pivotal in further development.

With the entrance of the second theme sounding as an answer (though with a shade of doubt and/or inner strain) the dialog becomes more evident. Notwithstanding its inner contradictoriness, this theme appears as an intonational unity. This quality is inherited from the theme of "Voice", of which it is the derivative. The "answer", similarly to the theme of "Voice", is formed by two motives, though they sound more strained in manner: the fifth is diminished and so "sharpened", the sixth with its song-like, cantilena character is replaced by declamatory, recitative seventh, the tonal color is "thickened" by the diminution of the second.

In Homyakov's poem there is no traditional lyrical hero, but in its musical reading the presence of personality in its development and search for harmony is evident. So intensive is the development of the "terrestrial" intonation sphere that a certain musical and subject logic takes place. The interaction of "terrestrial" and "celestial" figurative-thematic spheres symbolizes a dialog between God and man: "God is calling us, and we are filled with this call, and we cannot understand it except in precisely this connection with Him" [8], i.e. in Love.

By the central quartet of "Psalm" (No.5), as a result of the accumulation of melodically and semantically similar themes, this figurative sphere endures a transformation, acquiring a new semantic aspect. While in previous numbers of the cantata the themes of questioning served as the initial thesis, the central quartet emphasizes the theme of the "answer", revealing the image of a human soul, and searching for harmony. In spite of the completeness of this theme, in its final fragment the themes of "question" (men's choir) and of Voice (the strings) can be heard. They seem to open the figurative and semantic bounds of this theme and give it a new meaning corresponding to the "comprehension of spiritual progress".
In the second part of the quartet the "theme of comprehension" takes the role of a new substantial modus responding to the image given in the poem ("The Earth from every corner is burning incense of fragrant flowers under dew"). Tense chromatic scales present in the theme since the introduction are reconsidered and interpreted now as an expression of awe "Fig.7" .

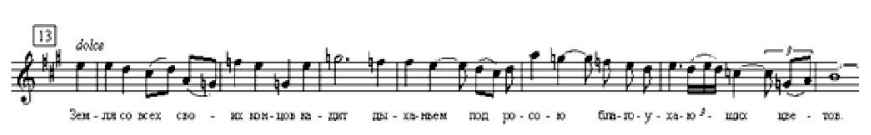

Fig. 7. Cantata “On reading Psalm”. Part II. Quartet No.5

Due to such a figurative transformation by the finale of the quartet, the initial character of the theme is changed. It is shortened (there is no more sequences of the theme's core), is tonally stable, it is only the forth that remains from the series of chromatic sounds. Besides, as a result of replacement of the descending leap by the seventh' (on the sixth) an enlightened, song conclusion emerges "Fig. 8 " .

The "reply" sphere in its new, affirmative meaning includes a flute solo theme from the introduction, based on a third "spinning" motive "Fig.9" .

Almost undistinguished in the introduction, here it serves as a step to the conclusive stage of the development of figurative content. It is noteworthy that the reverse variant of the theme (changeable sounds are not taken into account) coincides with the main "reply" theme (with the "feeling of doubt") from the first chorus. It reveals a calm, stable feeling opposite to anxiety and strain.

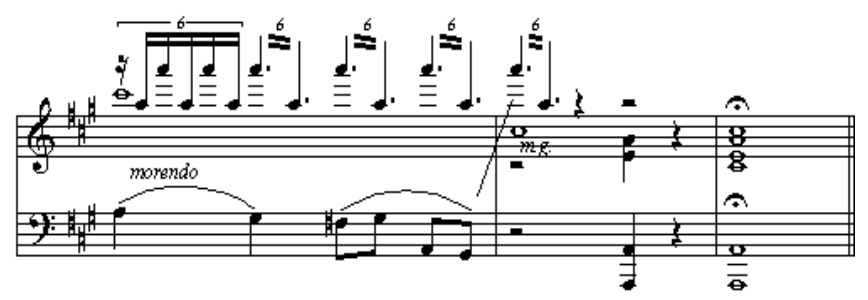

Fig. 8. Cantata “On reading Psalm”. Part II. Quartet No.5



Fig. 9. Cantata "On reading Psalm”. Part II part. Quartet No.5

Besides, this purely instrumental theme performs a function as an intonation idea-impulse, anticipating the appearance of a whole complex of "reply" versions, including the melodic material until the last choir. For example, the spinning motive in the third range is present in all the themes of Aria and in the second and third themes of the final fugue. The following theme-reply in the quartet is also its variant with third replaced by sixth, which is its inversion "Fig.10". 


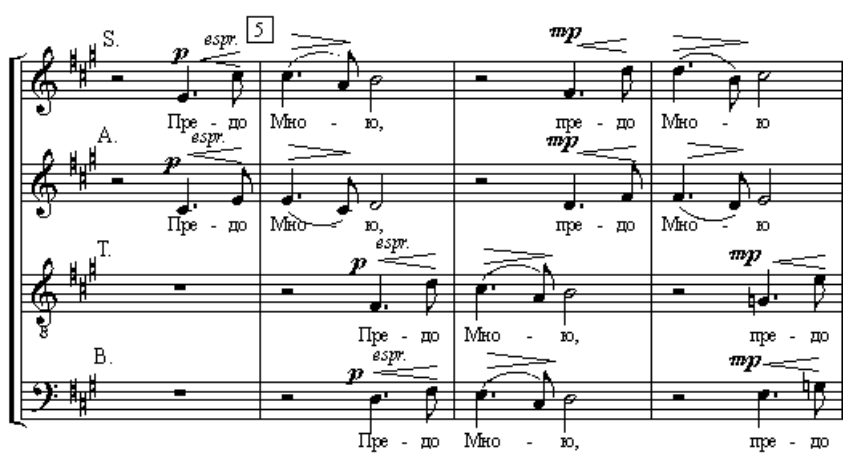

Fig. 10. Cantata “On reading Psalm”. Part II. Quartet No.5

It is the sixth that forms the intonational bases of the second element of the "question" theme of quartet No.5, from which develops the "reply" theme. The sixth" intonation acquires a special meaning also in the following variants of the "reply" theme (No.6, No.7, No.8 introduction) "Fig.11".

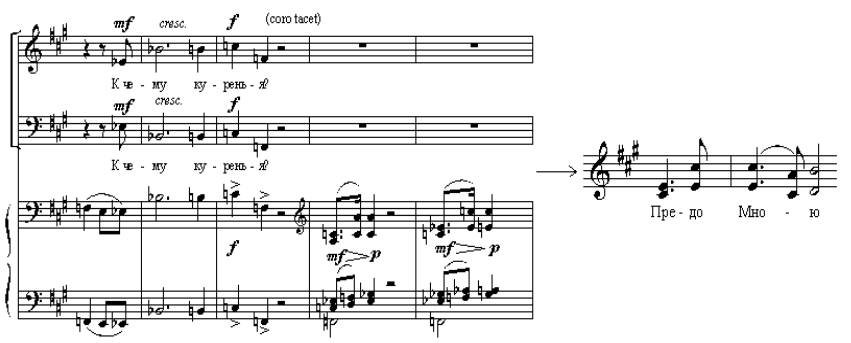

Fig. 11. Cantata “On reading Psalm”. Part II. Quartet No.5

After the sixth is established as the leading intonation by the end of the cantata, the melodious-lyrical principle has gained strength.

In the following (No. 6, 8, 9) the reply sphere is completely based on intonations rising straight from the "Voice" theme (fourth, fifth, on sounds of the triad) and forming beautiful joyous melodies.

Dialog in "Psalm" plays also the role of a structural pivot of the intonation process. In the first part the leading position is occupied by the intonations of "question" and suffering, in the second part the prevailing position is that of the "reply" or celestial sphere, and in the third part their interpenetration takes place. In "Psalm" "Voice" has its continuation in the Interlude (No.7) which serves an answer giving rise, in its turn, to the themes of the Aria and to the final Fugue, switching the music of the cantata to the figurative plane of stability, harmony, and peace. In "St. John", such a role is played by the central part sounding a capella, in full accordance with the fundamental tradition of the Old Russian singing art. The melody of the second part, extremely plastic and enlightened, directed upwards, is reminiscent of Russian temple architecture; represented graphically, its pattern resembles the contours of a church (like for example the Cathedral of St. Sophia in Kiev). Similarly to the disposition of a church's domes directed to the central one, which is the highest, Taneyev's melody is constructed with intonations, ascending and gradually descending to the initial pitch, each of them organized as an arc (a figure of balance) “Fig.12” .

The melody of the central part can be interpreted as an image of the Conciliarity or the Church affirmating the way of ascending from the terrestrial world in the beginning of the theme to the celestial one in its culmination. This is made through Love being understood as the main manifestation of a man's spiritual life realizing its meaning; it is a special state of the mind and the soul united with Christ. Such state is experienced by the believer's soul during the mass or, to use the expression of Nikolay Gogol, the "divine meal of love" the aim of which is the "unity with our brothers and with our Saviour" [9].
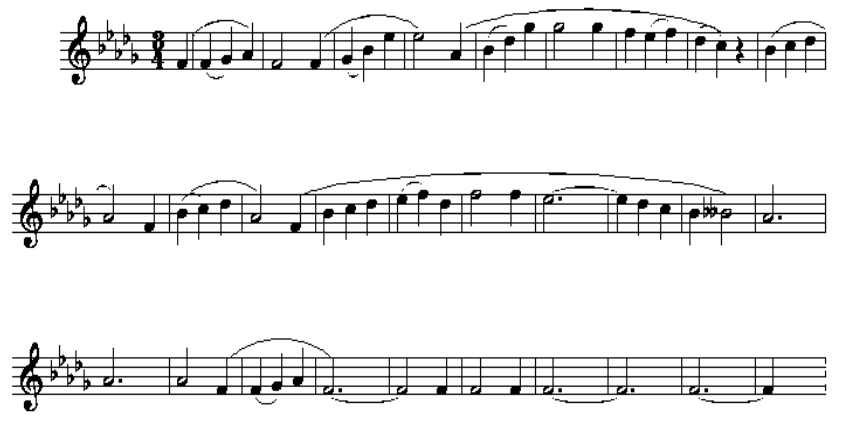

Fig. 12. Cantata "St. John Damascene". Part II

It is here that the logic of synergy rules the musical world. This statement can be proven by the fact that harmony seems to grow in the intonation and becomes, as Vyacheslav Medushevsky defines it, a modal harmony. In the second part of "St. John" and in all the choirs of "Psalm" the harmony only puts the symphony into an intonation shape, and as for functional motivations, they emerge additionally. Thus, the bass line in the beginning of the central part of "St. John" duplicates the soprano one in decima, has just the melodical bases; furthermore the most expressive supporting voices are sounded in the bass part duplicated by the alto (1). The twodimensional character of the musical texture due to redoubling is seen throughout the part.

Unlike the functional harmony which "is moving by jerks of inclinations and relaxations, reproducing the logic of human effort and the structure of psychological act", modal harmony is a "pure streaming, a delight of spiritual soaring, simultaneously moving in time and staying in eternity" [10].

Modality is also characteristic of the method of a "chain" intonation development, implying each newly appearing theme or its components is derived from the previous ones. The initial intonations of the cantatas (it is "For the peace"... in "St. John" and "Voice" in "Psalm") give rise to the "intonation cosmos".

\section{CHAIN INTONATION DEPLOYMENT IN TANEYEV'S CANTATAS}

The logic of such chain development in "St. John" conforms to the idea of spiritual progress through suffering that was established in the introduction. 
In "Psalm" the direction of the intonation stream depends on the transformation of the intonation complex rising from "Voice" according to figurative-emotional accents, nuances of poetic content, and respective psycho-emotional moduses and affects. For instance, a stable, contemplative character achieved by sounding a pure fifth, is switched over using its inversion to the semantics of a call typical of a pure fourth which develops tension, doubt, or the "diabolical temptation" characteristic of diminished fifth; interrogative intonation of ascending iambic sixth is transformed into an anxious seventh or, vice versa, into a calm and eventempered third "Fig.13".
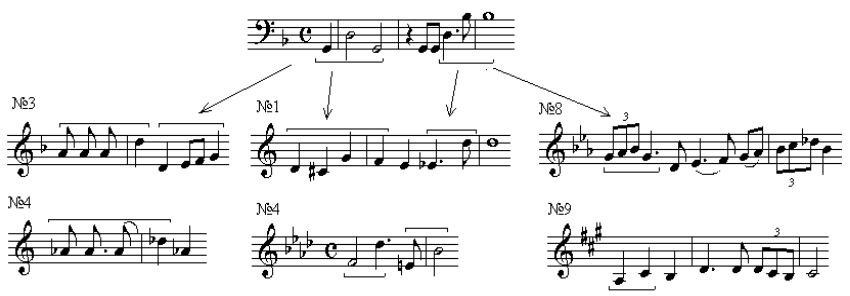

Fig. 13. Cantata "On reading Psalm"

An important role in the process of the emergence of a chain of themes-moduses belongs to the triad, either major or minor, the semantics of which contains primordially an idea of concord and harmony. In this connection, it suffices to mention the role of the fifth, the main interval of the triad, in the tonal system of ancient folk melodies or the function of triad in the classical major and minor system. Melodical movement by the steps of the triad directed towards the third tone is determined by the cantata's intonation archetype - the theme of "Voice" "Fig.14".

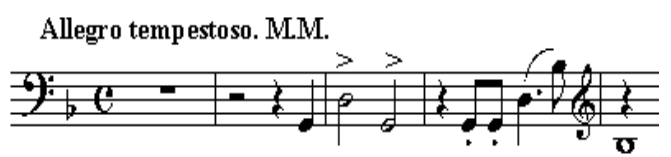

Fig. 14. Cantata "On reading Psalm”. No.1. Introduction

It determines the intonation bases of derivative moduses, or themes, which appeared under its influence "Fig.15".
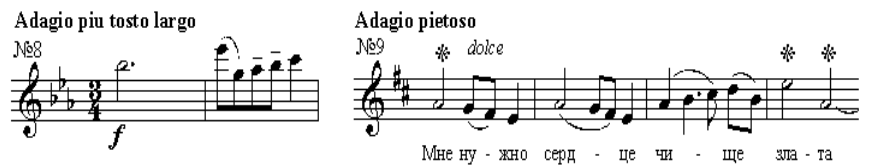

Fig. 15. Cantata "On reading Psalm”. No.8, 9

At the same time, the semantics of "call" or "appeal" built in the archetype becomes an active dynamizing factor of "reply" figurative sphere. Dialog as one of the cantata's dramatic principles is implemented not only at the compositional level (at the macrolevel), but also at the microlevel, i.e. at that of the intonation.

So, the method of "chain" development provides the intonation unity in spite of apparent variety of musical textural elements. The role of initial intonations can be compared with that of intonation-archetype in an echoes chant that serves an intonation model, a thesis or, in terms of West-European musical theory, a modus. This analogy can be also fortified by a special type of musical texture characteristic of Taneyev's manner, with its vocal-speech nature.

The leading role of dedicated moduses' movement in the form of the cantata similar to an endless intonation circle is predetermined by mainly linear character of musical texture.

In the light of Boris Asaphiev's formula the leading shape-generating role of the intonation principle allows consideration of the cantata's composition as a type with changing functions:

$$
\mathrm{i}: \mathrm{m}: \mathrm{t}(\mathrm{i}): \mathrm{m}: \mathrm{t}(\mathrm{i}) \ldots
$$

Variable functions prevailing over the basic or constant functions provide a continuity of form.

The interacting polyphonic and chant, or cantilena principles determine a method of melodical shaping which can be compared, to use B. Asaphiev's apt expression, with "bar embroidery". Monodical principles of musical form come to the foreground while polyphony serves an additional, secondary factor. Harmony in "Psalm" also plays an unusual role. Full cadences are rare and serve a sign of a special importance and exceptionality of a certain fragment. For instance, two cadences present in the first choir serve to accentuate the leading position of parts 21-23. Harmonic means (superposition of cadence and initial constructs or elliptic turns) contribute to wash out the compositional bounds and increase the continuity of melodical movement.

These means serve to emphasize such qualities characteristic of polyphony such as the absence of visible segmentation and the duality of the structural function of each construct.

\section{COMPOSITIONAL LOGIC CANTATAS}

Exceptional dynamism of form's procedural aspect is secured also by the intonation's "popevochny" (melodic) logic of its composition. Such interaction of monodical and polyphonic principles provides an exceptional unity of ternary composition owing to at least two special features of musical formation present in both cantatas. The former is predetermined by the principle of continual intonation renewal. The latter consists in the fact that different moduses-versions of the archetype are constructed each time by the semantic reinterpretation of its intonation microelements (usually by rhythmical changes).

Active catering to the "transfiguration" is also revealed in the tonal aspect of "Psalm" directed from the strained and dramatic D minor through A major, $\mathrm{C}$ sharp minor and $\mathrm{E}$ flat major to the hymnic D major:

$$
d \underbrace{\text { DesA Des }}_{d \rightarrow F}
$$

One more important compositional feature of "Psalm" and "St. John" is an "endless circle" which can be interpreted in the figurative aspect as an expression of a human soul's 
eternal aspiration to divine perfection. In terms of theology this process is called deification by grace. It is interesting that this perpetual motion has a form of a ball, i.e. an outboard surface of spiral rotation, which is from the earliest times considered a symbol of absolute perfection, or God.

All the features of form observed - dialogic character, chain logic of development, continuity - allow one to characterize this opus as a compositional entity with a prologue where the instrumental Interlude (No.7) serves as a synthesizing reprise. Aria and the final Fugue form an epilogue with common material and sense, in which the main idea of the opus is revealed in musical aspect as well as in verbal-poetic one.

The dialectic of dynamics and statics typical for this form is projected to the cantata's composition in the following way: the "framing" method, which is the main principle of the opus at the level of each "number" as well as at that of the whole organization, is like a system of broadening circles leading to the centre of the "ball". In "St. John" it is the melodical summit (the initium) of the central part's theme; in "Psalm" it is the central part of the Quartet (No.5). The dynamics of intonation process are directed to this point and then it returns back to the initial thesis ("Voice", "For the peace...").

In "St. John" the concentricity of form is typical in the first part. It emerges owing to the part in which the melody of "God rest the soul...." alternates with the theme "My eye...". Overall it provokes figurative-semantic analogies with the music of a funeral rite that is organized in similar way. Special dramatic importance of this part (let us mark it as " $\mathrm{B}$ ") is seen also at the compositional level: it appears twice, "squeezed" into the traditional fugue form, destroying its classical scheme. As a result, a fugue-like form with elements of concentricity emerges. It is one of so-called synthetic forms, in terms of Vladimir Protopopov.



Concentricity is characteristic of "St. John" in the whole. In the first and the last parts the melody "For the peace..." is combined with the main themes revealing man's inner world. Here it is augmented and can be interpreted as the divine Voice, an expression of God's will penetrating all human beings and giving him an invincible firmness of spirit.

\section{CONCLUSION}

So, the composition of both cantatas shares characteristics of symmetry, sphericity, spiral movement of moduses, and continuity. In both cantatas progressive melodical movement ("cycle") accentuated by the "popevochny" (melodic) principle of melodical development is balanced with compositional symmetry. Their architectonical beauty is founded on the principle of threeness. In our case, ternary form natural for the logic of musical construction has a deep religious and philosophical basis (the idea of Trinity). This idea is revealed in a large measure through the specificities of timbre and musical texture. Thus, in "Psalm" each part of the opus reveals at the timbre level the human progress towards the sense of "we".
The sonorous choir in the first part is interpreted as the image of the Word, or of the God's will; the second part, with choral fugue and quartets, presents a soul on its way to transfiguration. In the third part the Aria performed by contralto, with its special warmth, rich timbre and strong choral unison reveal the confluence of multitude into a unity, which is possible only in Love.

In both cantatas, created in the time of flowering Russian thought, the idea of the perfect organization of life is filled with such meanings as "harmony", "concord", "reconciliation", and "love", all taking an important place in Russian philosophy at the turn of 19th century. Such a worldview explains the preference given by Taneyev to cantata, a large-scale choral genre. Revealing the idea of synergy, i.e. accord of two wills, and that God and human are one, the composer has reconsidered the genre of cantata in an orthodox vein.

\section{REFERENCES}

[1] M. Aranovsky. Symphonic search. The problem of symphony genre in Soviet music in 1960-1975.- Leningrad, 1979. P. 16.

[2] V. Lossky. Essays of mystical theology of the Eastern Church.Moscow, 1991. P.21.

[3] A. Homyakov. Complete works. V. 2. Theological works.-Prague, 1867. P. 294.

[4] V. Medushevsky. Intonation form of music.-M., 1993. P.27.

[5] A. Schweitzer . I.S. Bach. - Moscow, 1964. P. 345.

[6] Akaluthia of burial of deceased// Pskov collection. Manuscript of the beg. of $20^{\text {th }}$ cent. OP and PK GPB funds. P. 5.

[7] A. Homyakov. Complete works. V. 2. Theological works. - Prague, 1867. P. 15.

[8] V. Lossky. Essays of mystical theology of hte Eastern Church. - M., 1991. P. 206.

[9] V. Lossky. Essays of mystical theology of the Eastern Church. Moscow, 1991. P. 34.

[10] V. Medushevsky. Intonation form of music. - Moscow, 1993. P.37 